Discussion Paper No. 03-05

\title{
Do Ukrainian Firms Benefit from FDI?
}

Stefan H. Lutz and Oleksandr Talavera

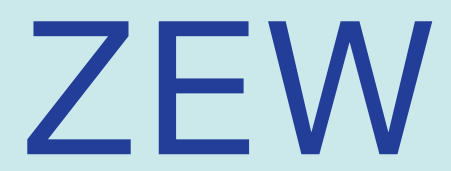

Zentrum für Europäische Wirtschaftsforschung GmbH

Centre for European Economic Research 
Discussion Paper No. 03-05

\title{
Do Ukrainian Firms Benefit from FDI?
}

\author{
Stefan H. Lutz and Oleksandr Talavera
}

Download this ZEW Discussion Paper from our ftp server:

\section{ftp://ftp.zew.de/pub/zew-docs/dp/dp0305.pdf}

Die Discussion Papers dienen einer möglichst schnellen Verbreitung von neueren Forschungsarbeiten des ZEW. Die Beiträge liegen in alleiniger Verantwortung der Autoren und stellen nicht notwendigerweise die Meinung des ZEW dar.

Discussion Papers are intended to make results of ZEW research promptly available to other economists in order to encourage discussion and suggestions for revisions. The authors are solely responsible for the contents which do not necessarily represent the opinion of the ZEW. 


\section{Non-Technical Summary}

In 1991, Scotland paid 50.75 million pounds for Motorola to locate a mobile-phone factory employing 3,000 people. In the late 1980s, Toyota was offered an incentive package worth 125--147 million dollars in present value for a plant expected to employ 3,000 workers. Other empirical studies have found positive effects of foreign direct investment (FDI) on different indicators of firm's performance in Indonesia, Russia and Lithuania.

These studies show that an increase in FDI leads to an increase in the level of local capability and competition. However, the results vary across countries and across industries within a particular country. Theory tells us that FDI has direct and indirect impacts. Direct FDI effects contribute to the differences in performance of firms with and without FDI. Indirect (or spillover) effects are spread through specific contacts between multi-national corporations (MNCs) and domestic firms. Negative spillovers have been found, for example, for Venezuela, Romania and Poland. While some empirical work on FDI has been done for several transition countries, this is not the case yet for Ukraine.

Using unpublished Ukrainian micro data, we examine the effects of the presence of FDI on the performance of individual Ukrainian firms receiving that FDI. Performance may be measured as sales or as exports. These direct effects may indicate technology transfer taking place in addition to capital investment. Secondly, we investigate the effects of the presence of FDI on the performance of firms not receiving FDI in the same industry or the same region. These indirect effects, if present, would indicate spillovers. We anticipate positive, but low, direct and indirect effects on both sales and exports of Ukrainian firms. We also expect that foreign-owned establishments have comparatively higher levels of performance and domestic establishments exhibit significant benefits from spillovers.

The results received imply that the presence of FDI has a positive influence on both labor productivity and exports. The four regions investigated did not exhibit significant differences. In addition, we found small, positive spillover effects on both labor productivity and export volumes of firms that did not themselves receive FDI. Our results also imply some differences across industries and across different ownership types. 


\title{
Do Ukrainian Firms Benefit from FDI? ${ }^{1}$
}

\author{
Stefan H Lutz and Oleksandr Talavera ${ }^{2}$ \\ (ZEW; Boston College)
}

\section{JANUARY 2003}

All countries are eager to attract as much foreign investments as possible. At the same time FDI may have not only positive, but also negative economic effects for receiving countries. Positive effects are associated with technology transfer, efficient allocation of resources, and training of domestic workers. However, the entry of foreign firms could, e.g., lead to a decrease of labor productivity at domestic firms, which is a negative effect. The main purpose of this paper is to estimate direct and indirect effects of FDI. First, we test for direct influence of foreign direct investments on firms' performance, where the latter is estimated alternatively as labor productivity and as exports. FDI notably increases both labor productivity and export volumes. Second, we look for spillover or indirect effects. There is statistical evidence that the levels of FDI in certain regional industries are associated with higher performance indicators of firms' not receiving FDI in those same regional industries.

JEL classification: L1, L6, F2

Keywords: Foreign direct investment, firm performance, spillovers, Ukraine

\footnotetext{
1 This work is based on Talavera (2001).

${ }^{2}$ Contact information: Stefan H Lutz, ZEW - Centre for European Economic Research, Department of Industrial Economics and International Management, L7, 1, D-68161 Mannheim, Germany, T. +49-621-1235-295 (F. -170), lutz@zew.de; Oleksandr Talavera, Boston College, 135 Chiswick Road, Brighton 02135, MA, USA, T. 617-787-8792, talaveol@bc.edu. The authors acknowledge partial support by the Economics Education Research Consortium (EERC - Kiev) through research project RP01-02. We are also grateful to Hartmut Lehman, Christopher F. Baum and Inessa Love for crucial advice in the empirical part, as well as to Roy Gardner, Jurek Konieczny, and two anonymous referees for several useful comments and suggestions. Finally, we wish to thank our colleagues at the EERC MA Program for their support.
} 


\section{Introduction}

In 1991, Scotland paid 50.75 million pounds for Motorola to locate a mobile-phone factory employing 3,000 people. In the late 1980s, Toyota was offered an incentive package worth 125--147 million dollars in present value for a plant expected to employ 3,000 workers (Haskel et al., 2001). Ireland encourages FDI by introduction of National Development Plan that increases the value and sustainability of foreign companies, and secures their future. ${ }^{3}$ Why does government attract FDI? Is FDI always beneficial for a country? During the last few years many scholars have raised this question. While attracting FDI is an important issue in itself, international investments may also lead to different externalities. As a rule, FDI to a particular firm in a particular industry may give rise to positive effects on the performance of other firms that entertain business relations with the FDI-recipient. However, we cannot unambiguously assert these effects of FDI in transition economies, and in Ukraine in particular. As a rule, transition changes the way economy operates and may lead to unexpected results. Therefore FDI can bring both positive and negative externalities. Negative spillovers could occur in the form of raised monopoly power of multi-national corporations (MNC). These MNCs may have a strong incentive to acquire and close Ukrainian competitors.

Recent empirical studies carried out by Blomström and Sjoholm (1999), Ponomareva (2000), Smarzynska (2002) have found positive effects of FDI on different indicators of firm's performance in Indonesia, Russia and Lithuania. They show that an increase in FDI leads to an increase in the level of local capability and competition. However, the results vary across countries and across industries within a particular country. Furthermore, negative spillovers are found by Aitken and Harrison (1999), Konings (1999) for Venezuela, Romania and Poland. Theory tells us that FDI has direct and indirect impacts. Direct FDI effects contribute to the differences in performance of firms with and without FDI. Indirect effects are spread through specific contacts between MNCs and domestic firms.

The technology transfer effect appears when domestic firms receive new technologies and know-how for lower costs from MNCs. The catch-up effect simply means that foreign firm captures the share of local market or domestic firm looses its market share. At the same time, the latter effect may have positive influence on local firms. In this case,

${ }_{3}^{3}$ Department of Enterprise Trade and Employment, 10 January, 2000, http://www.entemp.ie/press00/100100a.htm 
it is called competition effect. Competition effect arises when entrance of foreign firms forces domestic firms to act more efficiently in order to protect their profits and shares. The foreign linkage effect appears when foreign companies use services supplied by local firms. Demonstration effect appears when a home firm, observing the behaviour of foreign company, tries to mimic it. Finally, the training effect is a situation when foreign firms provide training for their workers and managers, who in future can be hired by domestic firms.

Attracting Foreign Direct Investment has already become one of the most essential issues in the transformation and development of the Ukrainian economy. Because of substantial technological lags in comparison to developed countries, Ukraine could benefit from foreign capital inflows and the resulting international cooperation. This cooperation, in turn, could provide new technologies, new methods of management, and could also promote the development of domestic investments. Experiences of developed countries suggest, that often a domestic investment boom starts with the adaptation of new technologies, brought on with foreign capital.

Currently however, the Ukrainian level of FDI per capita is far below that of most other transition countries, in particular that of the Estonia, Hungary or Poland. For example, the USA only invested ten times more into the Polish economy than into the Ukrainian one $^{4}$. Such negligible volumes of FDI could be explained by the discouraging investment climate, presently prevailing in Ukraine. This is also represented by suspicious attitudes towards foreign investors displayed by both government officials and Ukrainian industry managers. To many international investors, it might seem that Ukraine, ex-ante, does not want to attract any FDI.

On the other hand, Ukraine has a substantial economic potential, which is not yet utilized adequately. With a population close to that of France, the domestic market is large. Both skilled and unskilled labor is relatively inexpensive, while the general level of education and skill is high. Finally, domestic firms do not yet pose a high level of competition.

Using unpublished Ukrainian micro data, we examine the effects of the presence of FDI on the performance of individual Ukrainian firms receiving that FDI. Performance may be measured as sales or as exports. These direct effects may indicate technology transfer taking place in addition to capital investment. Secondly, we investigate the effects of the

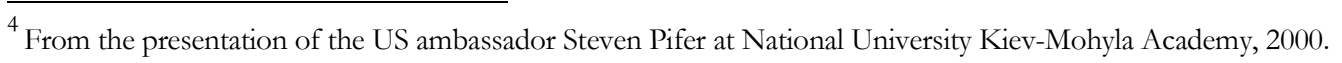


presence of FDI on the performance of firms not receiving FDI in the same industry or the same region. These indirect effects, if present, would indicate spillovers. We would anticipate positive, but low, direct and indirect effects on both sales and exports of Ukrainian firms. We would also expect that foreign-owned establishments have comparatively higher levels of performance and domestic establishments exhibit significant benefits from spillovers.

The rest of the paper is constructed as follows. Section 2 presents a short version of literature review. In Sections 3 we describe the data and discuss our empirical models results. Finally, Section 4 concludes and gives suggestions for further research.

\section{Is Foreign Direct Investment Good?}

"To attract companies like yours. we have felled mountains, razed jungles, filled swamps, moved rivers, relocated towns. all to make it easier for you and your business to do business here."

Why do governments want to attract FDI? The intuitive answer to this question is that governments receive benefits from having foreign firms in the country. Foreign companies hire local labor, increase aggregate demand and supply or affect the firm indicators directly. At the same time, there are also indirect effects or spillover effects. The channels of these effects are: technology transfer effect, competition effect, backward and forward linkage effect, training effect, and demonstration effect.

Describing indirect FDI effects, Blomstrom and Kokko (1997) discuss transfer and technology diffusion from multinational companies to host countries, as well as prevalent ownership of commercial technologies by multinational companies. The technology transfer channel is also theoretically analyzed by Blomstrom (1987). He concludes that " . such a transfer is a central activity of MNCs, and this may stimulate domestic firms to hasten their access to a specific technology". Ponomareva (2000) also examines the impact of technological spillovers from FDI on Russian domestic enterprises. She mentions a positive effect from FDI spillovers and concludes, "The effects [of FDI spillovers] depend on host country and host industry characteristics and the policy environment in which the multinationals operate". The author mentions an intra-region transfer of know-how and technology and finds that domestic firms located near multinationals benefit from this vicinity. Kinoshita (2000) examines the effect of

${ }^{5}$ From the advertisement placed in Fortune Magazine by the Philippine government, cited by D.C.Korten (1995). 
technology diffusion from FDI in explaining the total factor productivity growth. She uses unpublished firm-level data of the Czech manufacturing sector for period of 199598. She finds that both foreign joint ventures and foreign presence in the sector do not have significant effects on productivity. In addition, the rate of technology spillovers are different for different industries in the economy. In oligopolistic sectors such as machinery, there exists a significant rate of spillovers from large foreign presence and there is no evidence of strong spillovers in more competitive food, textile, wood and chemical industries.

As for competition effects, Blomstrom (1987) describes it as an increase in competition when multinational companies enter the Mexican markets that leads to a more efficient market structure. Blomstrom and Kokko (1997) also examine the influence of international companies on the performance of the host country, as well as the effects on competition and industry structure in the host countries. They conclude that FDI contributes to productivity growth and exports in host countries, yet the exact nature of correlation between foreign and domestic firms could vary among industries and countries: some industries are more protected by government, some are less protected. In a similar vein Ponomareva (2000) stresses the fact that competition with foreign firms forces domestic companies to protect their market share and profits. In contrast to the previous study, she finds negative effects and concludes that increase in foreign ownership negatively affects the productivity of Russian domestically owned firms in the same industry. Similarly, Konings (2000) finds negative spillovers in Bulgaria and Romania. He explains that increase in competition from FDI dominates technological spillovers to domestic firms. Inefficient firms loose market share due to foreign competition, which in the long run should increase the overall efficiency of an economy.

Blomstrom (1989) mentions that the training spillover channel can be a result of worker training by foreigners investing in human capital. This effect spreads not only on foreign companies but also on domestic firms. “In Mexico ... many managerial people in large locally owned firms started their career in a MNC, and management practices may in this way be substantially improved in domestic firms". Moreover, Kinoshita (1998) finds worker training an important source of productivity growth. However, it has some peculiarities. Domestic firms are afraid of loosing their market shares and they invest funds to to train their workers and managerial personnel At the same time she finds that foreign firms are unlikely to invest in the education of local workers. 
Blomstrom and Kokko (1997) distinguish backward linkage and forward linkage effects. A backward linkage occurs during interaction between multinational companies' branches and suppliers. The authors suggest that backward linkage is associated with MNCs assistance in establishing production facilities by suppliers, increasing quality of raw materials and training of management. A forward linkage is associated with consumer-MNC relationships. This channel is less evident than the previous one, and Blomstrom and Kokko mention insignificance of the forward linkage effect. Similarly, Kinoshita (1998) also include foreign linkages proxy, but finds statistically insignificant coefficients.

Blomstrom and Kokko (1997) view demonstration effect as an important channel of spillovers. It arises when domestic firms try to mimic foreign firms in different areas of business activity. They suggest, that demonstration is often related to the competition effect and takes place uncousciously. Kinoshita (1998) determines the demonstrationimitation effect: when domestic firms observe activity of their multinational competitors they start to imitate or copy in order to become more productive.

In our research we want to investigate the direct and indirect effects of FDI. Indirect effect are spread through regional and industrial spillovers that correspond to backward linkage and competition spillover channels respectively.

We anticipate to find positive linkage effect while competition effect can be both positive and negative.

\section{Direct and Indirect FDI Effects}

\subsection{Data description}

The data used in this research consist of two EERC Research Center datasets. The first includes micro-level information on fixed assets, labor force, sales, export, import, barter operations, and industry-region information. The second contains information on FDI presence in certain firms.

Alternative estimations of fixed assets are used in the literature. Following Ponomareva (2000), our study uses the balance sheet value of fixed assets as proxy for capital, since this is the best available measure of real capital capacities of the firm. All data are at 
constant 1998 prices, converted using the producer price index from the UEPLAC (2000) web site ${ }^{6}$ (See Table 1).

Our data contains 292 observations of manufacturing firms for the years 1998 and 1999. 25 per cent of these firms have received FDI. A firm is assumed to be a recipient of FDI if:

- The firm is under foreign ownership; or

- The firm reported a change in the level of FDI received during last period.

The data set covers four regions: Lviv, Kyiv, Odesa and Kharkiv. These regions represent West, Center, South and East of Ukraine, respectively. The regional distribution with frequencies and percentages is described in Table 2. As can be seen from the Table 2, the share of Kyiv, Lviv and Kharkiv regions is 30\% each, while the share of Odesa region is $10 \%$. This may be explained by the fact that the Ukrainian South is less industrialized than the central or eastern areas.

Table 1. Statistic characteristics of variables used in this research.

\begin{tabular}{|l|l|l|l|l|}
\hline \multicolumn{1}{|c|}{ Indicator } & \multicolumn{2}{c|}{ All firms } & \multicolumn{2}{c|}{ FDI firms } \\
\hline & Mean & Std. Dev. & Mean & Std. Dev. \\
\hline Ualance value of fixed assets, & 17324.32 & 54366.9 & 5904.55 & 12853.74 \\
\hline Sales, UAH 1998 & & & & \\
\hline Imports, UAH 1998 & 5026.05 & 15245.07 & 3353.26 & 7379.38 \\
\hline Production, UAH 1998 & 902.15 & 3525.32 & 1548.95 & 3914.26 \\
\hline Labor force, \# of employees & 5169.32 & 15474.25 & 3948.94 & 10837.29 \\
\hline Exports, UAH 1998 & 457 & 1019 & 255 & 508 \\
\hline
\end{tabular}

Table 2. Region distribution of firms.

\begin{tabular}{|l|l|l|l|l|}
\hline Region & \multicolumn{2}{|l|}{ All firms } & FDI firms \\
\cline { 2 - 4 } & Frequency & Percentage & Frequency & Percentage \\
\hline
\end{tabular}

${ }^{6}$ Available at http://www.ueplac.kiev.ua 


\begin{tabular}{|l|l|l|l|l|}
\hline Kyiv region & 88 & 30.14 & 22 & 30.14 \\
\hline Lviv region & 90 & 30.92 & 26 & 35.62 \\
\hline Kharkiv region & 89 & 30.48 & 22 & 30.14 \\
\hline Odesa region & 25 & 8.56 & 3 & 4.10 \\
\hline
\end{tabular}

The data set covers seven industries. Most of the firms are involved in food industry (25 per cent) or in metal processing (20 per cent). However, a large number of firms do not identify themselves as belonging to any particular industry (22 per cent). The industry distribution of firms is summarized in Table 3.

Table 3. Industry distribution of firms

\begin{tabular}{|l|l|l|l|l|}
\hline \multirow{2}{*}{ Industry } & \multicolumn{2}{|l|}{ All firms } & \multicolumn{2}{l|}{ FDI firms } \\
\cline { 2 - 5 } & Frequency & Percentage & Frequency & Percentage \\
\hline Metallurgy & 24 & 8.22 & 5 & 6.85 \\
\hline Metal processing & 58 & 19.86 & 8 & 10.96 \\
\hline Wood and Paper & 15 & 5.14 & 5 & 6.85 \\
\hline Construction & 26 & 8.90 & 5 & 6.85 \\
\hline materials & & & & \\
\hline Light & 30 & 10.27 & 9 & 12.33 \\
\hline Food & 74 & 25.34 & 18 & 24.66 \\
\hline Others & 65 & 22.26 & 23 & 31.51 \\
\hline
\end{tabular}

Table 4. Ownership distribution of firms ${ }^{7}$

\begin{tabular}{|l|l|l|}
\hline Ownership & Frequency & Percentage \\
\hline Workers & 49 & 16.78 \\
\hline Managers & 13 & 4.45 \\
\hline Government & 7 & 2.40 \\
\hline
\end{tabular}

7 On the basis on major ownership. 


\begin{tabular}{|l|l|l|}
\hline Other physical entities & 27 & 9.25 \\
\hline Other Ukrainian companies & 29 & 9.93 \\
\hline Other foreign companies & 61 & 20.89 \\
\hline Other & 106 & 36.30 \\
\hline
\end{tabular}

The ownership structure of available data is depicted in Table 4. A significant share of firms $(36 \%)$ did not report their form of ownership. Workers own $17 \%$ of firms in the sample. Other physical entities are either retired persons or those who bought shares during certificate auctions.

\subsection{The Econometric Models Employed}

The main aim of this paper is to estimate the influence of FDI on firms' performance and to identify region-industry spillover effects.

In order to estimate the former effect, we develop the following analytical model:

$$
P_{i t}=f\left(K_{i t}, L_{i t}, \text { Industry }_{i}, \text { REGION }_{i}, F D I_{i}, \text { OWNERSHIP }_{i}, \text { Scale }_{i t}\right)
$$

where

$\mathrm{i}$ - index for firm, and $\mathrm{t}-$ index for year;

$P_{i t}$ - firm performance, estimated as labor productivity or export volume;

$L_{i t}-$ labor, i.e. the number of workers in the firm;

$K_{i t}$ - capital stock or the balance value of fixed assets;

Scale $_{i t}$ - proxy for economies of scale, estimated as the ratio of a firm's production to the average production in the industry;

INDUSTRY $Y_{i}$ - industry, one of the seven industries according to the specification of the EERC Research Center;

OWNERSHIP - type of ownership, one of types of ownership according to the specification of the EERC Research Center;

REGION $_{i}$ - region, where the firm is situated;

$F D I_{i}$ - a dummy variable that shows the existence of FDI. 
The dependent variable, i.e. performance, could be estimated in various ways. The ideal representation would be value added or value added per worker. However, due to data restrictions, only the variables sales, production, barter, export and import were available to us for that purpose. , The Hausman specification test was used to identify the correct econometric specification ${ }^{8}$.

The econometric specifications selected are shown below.

Model 1. Labor productivity is assumed to be a performance indicator and our model is:

$$
\begin{aligned}
& \ln \frac{Y_{i t}}{L_{i t}}=\text { const }+\alpha_{1} \ln \frac{K_{i t}}{L_{i t}}+\alpha_{2} F D I_{i}+\sum_{\rho=1}^{3} R_{\rho} R_{E G I O N_{\rho i}}+ \\
& \sum_{\sigma=1}^{6} S_{\sigma} I N D U S T R Y_{\sigma i}+\sum_{\delta=1}^{6} O_{\delta} O W N_{\delta i}+\varepsilon_{i t}
\end{aligned}
$$

where

$F D I$, is a dummy variable taking the value 1 if the firm has ever received foreign direct investments, and 0 otherwise.

REGION, INDUSTRY, are dummies, which specify an industry and region, respectively. For the regional dummies, the Odesa region is the base, and $R_{1}$ denotes Kyiv, $R_{2}-$ Lviv, and $R_{3}$ - Kharkiv. The unspecified industry category is the base for the industry dummies, and the other dummies are: $S_{1}$ - metallurgy, $S_{2}$ - metal processing, $S_{3}$ - wood and paper, $S_{4}-$ construction materials, $S_{5}-$ light industry and $S_{6}-$ food industry.

$O W N_{o i}-$ are dummies that determine the type of ownership. The unspecified ownership category is the base for the ownership dummies. We denote $O_{1}$ - workers ownership majority, $\mathrm{O}_{2}$ - management, $\mathrm{O}_{3}$ - state, $\mathrm{O}_{4}$ - other physical entities, $\mathrm{O}_{5}$ - other Ukrainian companies and $\mathrm{O}_{6}-$ other foreign companies.

Our hypotheses for model 1 are as follows:

$\mathrm{H1}_{0}: \alpha_{2}=0$ : Receiving FDI does not affect labor productivity of the receiving firm.

$\left(\mathrm{H} 1_{1}: \alpha_{2}>0\right.$ : FDI has a significant influence on labor productivity $)$

As is customary, we anticipate the rejection of our null hypothesis.

\footnotetext{
8 As we have time invariant FDI dummy variable, fixed effect models do not help us to estimate the affect of FDI on firms' indicators. Random effect models have to be employed. The validity of this approach has to be checked with Hausman specification test for random effect.
} 
Model 2. Here, performance is measured by export volume. If a firm exports more, this may be interpreted as a sign of comparative advantage. This model has basically the same structure as model 1, but a proxy for economies of scale, estimated as the ratio of firm's production to the average production in industry, was added. Furthermore, separate variables for capital and labor were used instead of the labor productivity variable.

$$
\begin{aligned}
& \ln \operatorname{Exp}_{i t}=\text { const }+\alpha_{1} \ln K_{i t}+\alpha_{2} \ln L_{i t}+\alpha_{3} F D I_{i}+\sum_{\rho=1}^{3} R_{\rho} \text { REGION }_{\rho i}+ \\
& \sum_{\sigma=1}^{6} S_{\sigma} \operatorname{INDUSTRY}_{\sigma i}+\text { Scale }_{i t}+\sum_{\delta=1}^{6} O_{\delta} O W N_{\delta i}+\varepsilon_{i t}
\end{aligned}
$$

Our null hypotheses now takes the form:

\section{$\mathrm{H} 2_{0}: \alpha_{3}=0$ : Receiving FDI does not affect export volumes of the receiving firm.}

Both models presented above may be affected by endogeneity. A priori, we might expect that firms receiving FDI will have higher labor productivity as a result, and firms with higher labor productivity attract more FDI. The same links can be traced between FDI and export. FDI results in many cases in higher export volumes, and conversely, large export volumes attract FDI.

To correct for this endogeneity problem, we applied the following two-stage methodology. While FDI is highly correlated with exports, the latter, in turn, is not closely correlated ${ }^{9}$ with labor productivity. Therefore, as a first step, we constructed the following measure: ${ }^{10}$

$$
F D I_{i}^{*}=c o n s t+\alpha \ln E X P_{i t}+\varepsilon_{i t}
$$

and as a second step, using GLS in order to avoid heteroscedasticity, we estimated:

$$
\begin{aligned}
& \ln \frac{Y_{i t}}{L_{i t}}=\text { const }+\alpha_{1} \ln \frac{K_{i t}}{L_{i t}}+\alpha_{2} \text { FDI }_{i} *+\sum_{\rho=1}^{3} R_{\rho} \operatorname{REGION}_{\rho i}+ \\
& \sum_{\sigma=1}^{6} S_{\sigma} I_{\text {INDUSTR }}+\sum_{\delta=1}^{6} O_{\delta} O W N_{\delta i}+\varepsilon_{i t}
\end{aligned}
$$

${ }^{9} R^{2}=0.15$

${ }^{10} \mathrm{FDI}^{*}$ is a latent variable derived from probit estimation. 
Thus, we estimated the real effect of FDI on labor productivity. Similarly, estimations were performed with exports as indicator of firm performance:

$$
\begin{aligned}
& F D I_{i}^{*}=\text { const }+\alpha \ln \frac{Y_{i t}}{L_{i t}}+\varepsilon_{i t}(6) \\
& \ln \operatorname{Exp}_{i t}=\mathrm{const}+\alpha_{1} \ln K_{i t}+\alpha_{2} \ln L_{i t}+\alpha_{3} F D I_{i} *+\sum_{\rho=1}^{3} R_{\rho} R E G I O N_{\rho i}+ \\
& \sum_{\sigma=1}^{6} S_{\sigma} \text { INDUSTRY }_{\sigma i}+\text { Scale }_{i t}+\sum_{\delta=1}^{6} O_{\delta} O W N_{\delta i}+\varepsilon_{i t}
\end{aligned}
$$

We anticipate that FDI has a positive effect on firm's performance estimated as labor productivity or export.

In models 3-4, we investigate whether a firm that does not directly receive FDI benefits indirectly from FDI in other firms in its industry-region. In other words, we want to estimate the influence of FDI intensity, which is represented as a share of investment in a certain region-industry, on performance of firms that do not themselves receive FDI.

When estimating these indirect effects, there is less potential for endogeneity ${ }^{11}$, as we do not expect the productivity of firms that do not receive any FDI to be affected by the proportion of FDI in other firms in their industry-region. It is not likely that FDI in the industry-region should somehow be correlated with the labor productivity of firms that do not get any FDI. To control for unobserved heteroscedasticity we again use GLS for these three models.

Model 3. Using labor productivity as a measure of firm performance, our model becomes:

$$
\ln \frac{Y_{i t}}{L_{i t}}=\mathrm{const}+\alpha_{1} \ln \frac{K_{i t}}{L_{i t}}+\lambda S P I L_{\sigma \delta i}+\sum_{\delta=1}^{6} O_{\delta} O W N_{\delta i}+\sum_{\sigma=1}^{6} S_{\sigma} I N D U S T R Y_{\sigma i}+\varepsilon_{i t}
$$

Regional dummies have been dropped in this specification, because their coefficients turned out to be insignificant. The spillover variable is defined as the percentage of FDI in

\footnotetext{
${ }^{11}$ We thank Inessa Love from Columbia University for clarifying this point.
} 
the particular region multiplied by the percentage of FDI in the industry of the particular non-FDI-receiving firm.

Thus, the null hypothesis for model 3 becomes:

$H 3_{0}: \lambda>0$ : Receiving FDI does not increase labor productivity of other firms in the same region and industry.

Model 4. Here, we use exports as a proxy for firms' performance. The model takes the form:

$\ln \operatorname{Exp}_{i t}=$ const $+\alpha_{1} \ln K_{i t}+\alpha_{2} \ln L_{i t}+\lambda S P I L_{\sigma \delta i}+\sum_{\delta=1}^{6} O_{\delta} O W N_{\delta i}+\sum_{\sigma=1}^{6} S_{\sigma} I N D U S T R Y_{\sigma i}+\varepsilon_{i t}(9)$

The corresponding null hypothesis is then:

$H 4_{o}: \lambda \leq 0$ : Receiving FDI does not increase export volumes of other firms in the same region and industry.

We anticipate that FDI received by firms in a particular region and industry has a positive, possibly small effect on the performance of other firms in the same region and industry. Again, performance is measured by labor productivity and alternatively by exports.

In order to test all four hypotheses, we estimated and tested all four models. Our findings for the hypotheses testing are shown below for one representative specification each. More complete estimation results are presented in Tables 5-8 in the appendices.

Model 1 is estimated as variations of equation 5. We test for and estimate the FDI impact on labor productivity of the receiving firm.

\subsection{Model $1^{12}$. Effect of FDI on labor productivity.}

$$
\begin{aligned}
\operatorname{Ln}\left(Y_{i t} / L_{i t}\right)= & 3.36 * * *-0.04 \operatorname{Ln}\left(K_{i t} / L_{i t}\right)+0.77 F D I^{* * *}+0.07 R_{1 i}-0 . .32 R_{2 i}+0.16 R_{3 i}+ \\
+ & 0 . \\
& 10 I_{1 i}-1.10 I_{2 i} * * *+0.06 I_{3 i}-1.84 I_{4 i} * * *-1.12 I_{5 i}^{* * *+}+88 I_{6 i} * * *+ \\
& +.53 O_{1 i}+0.66 O_{2 i}+0.04 O_{3 i}+0.41 O_{4 i}-0.37 O_{5 i}+0.57 O_{6 i}^{* *}
\end{aligned}
$$

It could be concluded for all model variations, that FDI has a positive and significant impact on the labor productivity of the receiving firm. Consequently, we reject our null

$12 *, * *, * * *$ mean $10 \%, 5 \%$ and $1 \%$ significance level respectively. 
hypothesis $\mathrm{H}_{0}$. Regional dummies are not significant, suggesting that there are no significant differences in the effects of FDI among the Kyiv, Kharkiv, Odesa and Lviv regions. As for differences between industries, labor productivity turns out to be relatively low in metal processing $\left(\mathrm{S}_{2}\right)$, the construction materials industry $\left(\mathrm{S}_{4}\right)$, and the light industry $\left(\mathrm{S}_{5}\right)$, but relatively high in the food industry $\left(\mathrm{S}_{6}\right)$. Among ownership dummies, only the foreign-ownership dummy is significant and has a positive impact. Foreign-owned firms have higher labor productivity. So, we could suggest that our zero hypothesis is rejected statistically.

\subsection{Model 2. Effects of FDI on exports}

In order to test our second hypothesis, we estimated the model from equation 7. Again, we show one representative specification below, and present more complete results in table 6 in the appendices. The FDI dummy is significant and positive, which suggests that $\mathrm{H}_{2}$ is econometrically incorrect. Expansion in the export volume depends on labor. Regional variables are again not significant, which suggests the absence of regional differences. Light industry $\left(\mathrm{S}_{5}\right)$ firms have higher export volume. This could indicate that the light industry is more export-oriented than others, because it is labor intensive and Ukraine has relatively inexpensive and high-skilled labor. The coefficients of other industry dummies are not significant.

$$
\begin{aligned}
\operatorname{Ln}\left(E_{X X} P_{i t}\right)= & 844.63 * * *+0.09 \operatorname{Ln}\left(K_{i t}\right)+.95 \operatorname{Ln}\left(L_{i t}\right) * * *+52.22 F D I * * * \\
& -0.14 R_{1 i}-.48 R_{2 i}-.45 R_{3 i}-0.01 S c a l e+ \\
+ & 0.32 I_{1 i}+0.78 I_{2 i}+0.31 I_{3 i}+0.72 I_{4 i}+1.41 I_{5 i} * *-0.80 I_{6 i} *+ \\
+ & 0.01 O_{1 i}+0.07 O_{2 i}+113 O_{3 i}+0.52 O_{4 i}+0.97 O_{5 i}+2.08 O_{6 i} * * *
\end{aligned}
$$

With respect to ownership effects, we note that only two of our dummy variables are significant; these are the state $\left(\mathrm{O}_{3}\right)$ and foreign ownership $\left(\mathrm{O}_{6}\right)$ dummies. Export orientation of foreign owners can be explained by the fact that production in Ukraine is less expensive than in some other countries due to inexpensive, high-skilled labor and tax privileges. The significance of state ownership could be a result of direct and implicit government subsidies. Implicit subsidies typically take the form of lower prices for gas, electricity and utilities, which are all either still owned or subsidized by the government. 


\subsection{Model 3. Spillover effects on labor productivity}

This model, as well as the next and last one, tests for spillover effects of FDI given to firms in a specific industry and region on other firms' performance in that same industry and region. Model 3 is described by equation 8 and illustrated below. More complete results are presented in table 7 in the appendices. This specification estimates the FDI-intensity effects (or spillover effects) on non-FDI firms' labor productivity.

$$
\begin{aligned}
& \operatorname{Ln}\left(Y_{i t} L_{i t}\right)=0.80 * * *+0.22 \operatorname{Ln}\left(K_{i t} / L_{i t}\right) * * *+0.002 \mathrm{spil} * * *+ \\
& +0.58 I_{1 i} * 0.77 I_{2 i} * * *+0.87 I_{3 i} * *-0.05 I_{4 i}-0.41 I_{5 i}+0.72 I_{6 i} *+ \\
& -0.15 O_{1 i}+0.12 O_{2 i}+0.45 O_{3 i}+0.03 O_{4 i}-0.59 O_{5 i} * *+0.07 O_{6 i}
\end{aligned}
$$

According to our results, the spillover variable (FDI intensity) is positive and significant at the $1 \%$ level. This suggests that positive FDI spillovers exist, but their quantitative effect is comparatively low. We may conclude that this is partly the result of generally low volumes of FDI in Ukraine. Furthermore, firms owned by other Ukrainian companies $\left(\mathrm{O}_{5}\right)$ perform worse than firms with other ownership types. This may be explained by a specific type of competitive behavior among Ukrainian firms. Business rivals buy shares of each other in order to have better access to raw materials. Non-FDI firms have lower labor productivity in metal processing $\left(\mathrm{S}_{2}\right)$ and wood industries $\left(\mathrm{S}_{3}\right)$. On the other hand, the metallurgy industry $\left(\mathrm{S}_{1}\right)$ experiences positive externalities.

\subsection{Model 4. Spillover effects on exports}

This final model stems from equation 8. It is again illustrated below, and more complete results are presented in table 8 in the appendices. This specification estimates the FDIintensity effects (or spillover effects) on non-FDI firms' export volumes.

$$
\begin{aligned}
& \operatorname{Ln}\left(E X P_{i t}\right)=-2.58+1.22 \ln \left(L_{i t}\right) * * *+0.003 \mathrm{spil}^{* * *+} \\
& +0.47 I_{1 i}-.60 I_{2 i}+1.24 I_{3 i}-1.14 I_{4 i}+0.53 I_{5 i}-0.55 I_{6 i} \\
& +0.37 O_{1 i}+0.74 O_{2 i}+1.32 O_{3 i} *+1.23 O_{4 i} *+1.12 O_{5 i}
\end{aligned}
$$


The spillover variable is positive and statistically significant, which implies the rejection of the null hypothesis for model 4. The coefficient of the spillover variable, however, is very small. The coefficient of the labor variable is positive and significant. None of the industry dummies are significant. But state-owned firms $\left(\mathrm{O}_{3}\right)$ and other physical entities $\left(\mathrm{O}_{4}\right)$ do exhibit higher exports than firms with other types of ownership.

\section{Conclusions}

Foreign direct investments to transition countries such as Ukraine are a highly appealing empirical research topic for several main reasons. For a poor transitional economy, foreign direct investments promise growth potential far beyond that available through domestic savings. Secondly, foreign direct investments could lead to several effects, both positive and negative. And, lastly, there exists little research of this type about Ukraine yet.

The effects of FDI may be grouped into direct and indirect impacts. Direct FDI effects measure differences in firm indicators between firms with and without FDI. Indirect (or spillover) effects are spread to firms that not themselves receive FDI, mostly through interactions between foreign and domestic firms. There are five main types of effects discussed in the relevant literature: technology transfer, catch-up, competition effect, foreign linkage effect and training effect.

Using unpublished micro-level annual data for 292 firms for the years 1998-99, we tested for statistical significance of FDI impacts on labor productivity (model 1) and export volume (model 2). Furthermore, we investigated spillover effect in models 3-4.

The results reported in the paper imply that the presence of FDI has a positive influence on both labor productivity and exports. The four regions investigated, i.e. Kyiv, Kharkiv, Odesa and Lviv, did not exhibit significant differences. In addition, we found small, positive spillover effects on both labor productivity and export volumes of firms that did not themselves receive FDI.

Our results also imply some differences across industries. According to model 1, firms from metal processing, construction materials and light industry exhibit relatively low balor productivity, while enterprises in the food industry enjoy a relatively high labor productivity. We can suggest from model 2 , that light industry companies export more then firms from other industries. According to Model 3, firms not receiving FDI in the 
metal processing and wood industries have lower labor productivity than others industries. At the same time, the metallurgy industry enjoys relatively high positive externalities.

Either foreign ownership or state-ownership present advantages for both labor productivity and export volumes, according to our results from models 1 and 2. A greater export orientation of foreign owners may be the result of several factors giving the foreign owner advantages in exports markets. The significance of state ownership with respect to labor productivity could be a result of Ukrainian government subsidies, tax privileges and similar policies. According to Model 3 results, firms not receiving FDI and owned by other Ukrainian companies perform worse than other firms with other ownership types.

While some empirical work on FDI has been done for several other transition countries, this is not the case yet for Ukraine. One might assume, that main reasons are problems related to data availability. Similar problems have constrained this research to a data set of less than 300 firms as well as only qualitative data on FDI. Consequently, we plan to work with larger data sets and more complete information on FDI volumes in the future. It would also be informative to estimate the effects of industry and regional spillovers separately. Finally, we would want to explore the effects of FDI on alternative indicators of firm's performance, such as value added and value added per worker.

\section{Literature}

1. Angelucci Manuela, Saul Estrin, Jozef Konings, and Zbigniew Zolkiewski. 2002. "The Effect of Ownership and Competitive Pressure on Firm Performance in Transition Countries: Micro Evidence from Bulgaria, Romania and Poland.” William Davidson working paper No. 434.

2. Aitken, Brian J. and Ann E. Harrison, 1999. Do Domestic Firms Benefit from Direct Foreign Investment? Evidence from Venezuela. American Economic Review, vol. 89, pp. 605--618.

3. Braconier Henrik, Karoline Ekholm and Karen Helene Midelfart Knavrik, 2001. Does FDI Work as a Channel for RD Spillovers? Evidence Based on Swedish Data. The Research Institute of Industrial Economics working paper No. 553.

4. Barrios Salvador, Sophia Dimelis, Helen Louri and Eric Strobi, 2002. Efficiency Spillovers from Foreign Direct Investments in the EU Periphery: A Comparative study of Greece, Ireland and Spain. Mimeo. CORE-Universite Catholique de Louvain.

5. Blomström Magnus. 1989. Foreign investment and Spillovers (Routledge).

6. ------- , Steven Globerman and Ari Kokko. 1999. The Determinants of host Country Spillovers from Foreign Direct Investment: Review and Synthesis of the Literature. The European Institute of Jananese Studies working paper No. 76. 
7. ------- and Sjoholm F. 1999. Technology Transfer and Spillovers: Does Local Participation with Multinationals Matter? European Economic Review, vol. 43, pp. 915--923.

8. Chung Wilbur. 2000. Identifying Technology Transfer in Foreign Direct Investment: Influence of Industry Conditions and Investing Firm Motives. Mimeo. New York University.

9. Davies, Howard. 1977. "Technology Transfer Through Commercial Transactions." Journal of Industrial Economics, Vol. 26, No. 2, pp.161-175.

10. Djankov Simeon and Bernard Hoekman. 2000. Foreign Investment and Productivity Growth in Czech Enterprises. World Bank Review, vol. 14, 49--64.

11. Estrin S. And A. Rosevear. 1999. "Enterprise performance and ownership: The case of Ukraine." European Economic Review, 43 pp.1125-1136.

12. Feinberg Susan and Sumit Majumdar. 2001. Technology Spillovers from FOreign Direct Investment in the Indian Pharmaceutical Industry. Mimeo. University of Maryland.

13. Filer Randall K. and Jan Hanousek. 2001. Data Watch: Research Data from Transition Economies. William Davidson working paper No. 416.

14. Grossman, G., and E. Helpman. 1991a. Innovation and Growth in the Global Economy (MIT Press).

15. Haskel, Jonathan E., Sonia C. Pereira and Matthew J. Slaughter, 2002. Does Inward Foreign Direct Investment Boost the Productiveity of Domestic Firms? NBER working paper No. 8724.

16. Herasymenko, V. 2000. "Foreign Direct Investment and its Role for Transition Countries." Conference materials on "Crossboarder Capital Flows in Transition Economies," mimeo., EERC-Kyiv.

17. Institute of Reform (2000). Економічні есе: рейтинг інвестиційної привабливості регіонів України у 1-му півріччі 2000 року, Vol 4.

18. Kinoshita, Yuko. 1998. "Technology Transfer through Foreign Direct Investments." Mimeo., CERGE.

19. Konings, Josef. 2000. "The Effects of Foreign Direct Investments, on Domestic Firms: Evidence from Firm Level Panel Data in Emerging Economies." Center for Economic Policy Research, Discussion Paper No.2586.

20. Korten D.C., 1995. When Corporations Rule the World, London. Earthscan, p.159.

21. Kudina, Alina. 1999. "The Motives for Foreign Direct Investment in Ukraine." Master's Thesis, mimeo., EERC-Kyiv.

22. Ponomareva Natalia, 2000. Are There Positive or Negative Spillovers from ForeignOwned to Domestic Firms? New Economic School, Working Paper No.BSP/00/042.

23. Sinani Evis and Klaus Meyer. Identifying Spillovers of Technology Transfer from FDI: The Case of Estonia. Centre for East European Studies, Copenhagen Business School.

24. Sinn, H.-W. and A. Weichenrieder. 1997. "Foreign Direct Investment, Political Resentment and the Privatization Process in Eastern Europe." Economic Policy: A European Forum, 0(24), April 1997, pp177-98. 
25. Smarzynska Beata, 2002. Does Foreign Direct Investment Increase the Productivity of Domestic Firms? In Search of Spillovers through Backward Linkages. World Bank Policy Research Working Paper 2923.

26. Svejnar Jan, 2001. Transition Economies: Performance and Challenges. William Davidson working paper No. 415.

27. Talavera, Oleksandr. 2001. "The Effect of Foreign Direct Investments on Firm Performance in Ukraine." Thesis, mimeo., EERC-Kyiv.

28. Yegorov, Igor. 1999. "Foreign direct investments in Ukraine: First results, Tendencies and Prospects." In Dyker, D.A. (ed.), Foreign Direct Investments and Technology Transfer in the Former Soviet Union (Edward Elgar), pp.155-188 . 


\section{Appendices}

\section{Regression results for Model 1}

Table 5. Effect of FDI on labor productivity.

\begin{tabular}{|c|c|c|c|c|}
\hline & $\ln \frac{Y_{i t}}{L_{i t}}$ & $\ln \frac{Y_{i t}}{L_{i t}}$ & $\ln \frac{Y_{i t}}{L_{i t}}$ & $\ln \frac{Y_{i t}}{L_{i t}}$ \\
\hline constant & $\begin{array}{c}3.110221 * * * \\
(.3798949)\end{array}$ & $\begin{array}{l}3.36888 * * * \\
(.6094581)\end{array}$ & $\begin{array}{c}3.797782 * * * \\
(.5813996)\end{array}$ & $\begin{array}{c}3.361068 * * * \\
(.6017184)\end{array}$ \\
\hline $\ln \frac{K_{i t}}{L_{i t}}$ & $\begin{array}{c}-.0321387 \\
(.0954852)\end{array}$ & $\begin{array}{l}-.0958973 \\
(.0990565)\end{array}$ & $\begin{array}{c}-.0777378 \\
(.0874039)\end{array}$ & $\begin{array}{c}-.0483727 \\
(.0878096)\end{array}$ \\
\hline$F D I$ & $\begin{array}{c}.7544024 * * * \\
(.1440682)\end{array}$ & $\begin{array}{c}.7314491 * * \\
* \\
(.1436722)\end{array}$ & $\begin{array}{c}.8042352 * * * \\
(.137226)\end{array}$ & $\begin{array}{c}.7737273 * * * \\
(.1398052)\end{array}$ \\
\hline $\begin{array}{l}\text { Kyiv } \\
\text { region }\end{array}$ & & $\begin{array}{c}.1963453 \\
(.4919964)\end{array}$ & $\begin{array}{l}.0382721 \\
(.4099749)\end{array}$ & $\begin{array}{c}.0755219 \\
(.4087269)\end{array}$ \\
\hline $\begin{array}{l}\text { Lviv } \\
\text { region }\end{array}$ & & $\begin{array}{l}-.5243072 \\
(.5092676)\end{array}$ & $\begin{array}{l}-.3578108 \\
(.4218442)\end{array}$ & $\begin{array}{l}-.3236778 \\
(.4304532) \\
\end{array}$ \\
\hline $\begin{array}{l}\text { Kharkiv } \\
\text { region }\end{array}$ & & $\begin{array}{c}-.00652 \\
(.5054732)\end{array}$ & $\begin{array}{c}.0584154 \\
(.4184861)\end{array}$ & $\begin{array}{l}.1697789 \\
(.420667)\end{array}$ \\
\hline $\begin{array}{l}\text { Metallurgy } \\
\text { industry }\end{array}$ & & & $\begin{array}{l}-.0532733 \\
(.3458821)\end{array}$ & $\begin{array}{l}.1002837 \\
(.3539814)\end{array}$ \\
\hline $\begin{array}{c}\text { Metal } \\
\text { processing }\end{array}$ & & & $\begin{array}{l}-1.2091 * * * \\
(.2727451)\end{array}$ & $\begin{array}{c}-1.105147 * * * \\
(.2791934)\end{array}$ \\
\hline $\begin{array}{l}\text { Wood and } \\
\text { paper }\end{array}$ & & & $\begin{array}{c}.2423589 \\
(.5650992)\end{array}$ & $\begin{array}{c}.069621 \\
(.5597583)\end{array}$ \\
\hline $\begin{array}{c}\text { Constructi } \\
\text { on } \\
\text { materials }\end{array}$ & & & $\begin{array}{c}-1.748438 * * * \\
(.6451326)\end{array}$ & $\begin{array}{c}-1.8427 * * * \\
(.661591)\end{array}$ \\
\hline $\begin{array}{c}\text { Light } \\
\text { industry }\end{array}$ & & & $\begin{array}{c}-.9461021 * * * \\
(.3357283)\end{array}$ & $\begin{array}{c}-1.122641 * * * \\
(.3374742)\end{array}$ \\
\hline $\begin{array}{c}\text { Food } \\
\text { industry }\end{array}$ & & & $\begin{array}{c}.8116791 * * * \\
(.3107219)\end{array}$ & $\begin{array}{c}.8844425 * * * \\
(.3141468)\end{array}$ \\
\hline $\begin{array}{c}\text { Workers } \\
\text { ownership }\end{array}$ & & & & $\begin{array}{c}(.5302774) \\
.3298891\end{array}$ \\
\hline Managers & & & & $\begin{array}{c}.6611196 \\
(.4943387) \\
\end{array}$ \\
\hline State & & & & $\begin{array}{c}.0459265 \\
(.4322602)\end{array}$ \\
\hline $\begin{array}{l}\text { Physical } \\
\text { entities }\end{array}$ & & & & $\begin{array}{c}.4110196 \\
(.3146988)\end{array}$ \\
\hline $\begin{array}{l}\text { Ukrainian } \\
\text { companies }\end{array}$ & & & & $\begin{array}{c}-.371814 \\
(.3498654)\end{array}$ \\
\hline $\begin{array}{c}\text { Foreign } \\
\text { companies }\end{array}$ & & & & $\begin{array}{c}.5729147 * * \\
(.2739975)\end{array}$ \\
\hline$R^{2}$ & 0.0671 & 0.1121 & 0.4654 & 0.5010 \\
\hline
\end{tabular}

In parentheses are standard errors; $*, * * * *$ mean $10 \%, 5 \%$ and $1 \%$ significance level respectively. 


\section{Regression results for Model 2}

Table 6. Effects of FDI on exports.

\begin{tabular}{|c|c|c|c|c|}
\hline & $\ln \operatorname{Exp}_{i t}$ & $\ln \operatorname{Exp}_{i t}$ & $\ln \operatorname{Exp}_{i t}$ & $\ln \operatorname{Exp}_{i t}$ \\
\hline constant & $\begin{array}{c}746.0346^{* * *} * \\
(123.3835)\end{array}$ & $\begin{array}{c}739.6532 * * * \\
(128.3026)\end{array}$ & $\begin{array}{c}952.2325^{* * *} * \\
(166.672) \\
\end{array}$ & $\begin{array}{c}844.6346^{* * * *} \\
(163.6355)\end{array}$ \\
\hline $\ln K_{i t}$ & $\begin{array}{c}-.065302 \\
(.1685712) \\
\end{array}$ & $\begin{array}{r}-.0754216 \\
(.177256) \\
\end{array}$ & $\begin{array}{l}.0375476 \\
(.17749) \\
\end{array}$ & $\begin{array}{c}.0927884 \\
(.1679689) \\
\end{array}$ \\
\hline $\ln L_{i t}$ & $\begin{array}{c}1.053925 * * * \\
(.2556936)\end{array}$ & $\begin{array}{c}1.059116^{* * *} \\
(.2603795) \\
\end{array}$ & $\begin{array}{c}.8663591 * * * \\
(.2800036)\end{array}$ & $\begin{array}{c}.9558322 * * * \\
(.2707489)\end{array}$ \\
\hline$F D I$ & $\begin{array}{c}46.0487^{* * *} \\
(7.622021)\end{array}$ & $\begin{array}{c}45.65519^{* * *} \\
(7.92957)\end{array}$ & $\begin{array}{l}58.7844 * * * \\
(10.30754)\end{array}$ & $\begin{array}{c}52.22984 * * * \\
(10.11333)\end{array}$ \\
\hline Kyiv region & & $\begin{array}{c}.1402472 \\
(.7403931)\end{array}$ & $\begin{array}{l}.0381235 \\
(.734901) \\
\end{array}$ & $\begin{array}{c}-.1492532 \\
(.6920088) \\
\end{array}$ \\
\hline Lviv region & & $\begin{array}{c}.00934 \\
(.7729364)\end{array}$ & $\begin{array}{l}-.0672211 \\
(.758352)\end{array}$ & $\begin{array}{c}-.4810016 \\
(.7283313)\end{array}$ \\
\hline $\begin{array}{l}\text { Kharkiv } \\
\text { region }\end{array}$ & & $\begin{array}{c}.0473668 \\
(.7619232)\end{array}$ & $\begin{array}{c}-.1459191 \\
(.7497495)\end{array}$ & $\begin{array}{l}-.4511203 \\
(.7099927)\end{array}$ \\
\hline $\begin{array}{c}\text { Metallurgy } \\
\text { industry }\end{array}$ & & & $\begin{array}{c}.2150633 \\
(.6217436) \\
\end{array}$ & $\begin{array}{c}.3292866 \\
(.6009516) \\
\end{array}$ \\
\hline $\begin{array}{c}\text { Metal } \\
\text { processing }\end{array}$ & & & $\begin{array}{c}.7478811 \\
(.5235675)\end{array}$ & $\begin{array}{c}.789942 \\
(.4958547)\end{array}$ \\
\hline $\begin{array}{c}\text { Wood and } \\
\text { paper }\end{array}$ & & & $\begin{array}{c}.4667229 \\
(1.011058)\end{array}$ & $\begin{array}{c}.315329 \\
(.9461807)\end{array}$ \\
\hline $\begin{array}{c}\text { Constructio } \\
n \text { materials }\end{array}$ & & & $\begin{array}{c}.1945991 \\
(1.184627)\end{array}$ & $\begin{array}{c}.725286 \\
(1.143566)\end{array}$ \\
\hline $\begin{array}{c}\text { Light } \\
\text { industry }\end{array}$ & & & $\begin{array}{c}1.660828 * * * \\
(.6113901)\end{array}$ & $\begin{array}{l}1.410261 * * \\
(.5931065)\end{array}$ \\
\hline $\begin{array}{c}\text { Food } \\
\text { industry }\end{array}$ & & & $\begin{array}{c}-.9703221 * \\
(.5672528)\end{array}$ & $\begin{array}{l}-.8042281 \\
(.543708)\end{array}$ \\
\hline Scale & & & $\begin{array}{c}-.0026378 \\
(.0595256) \\
\end{array}$ & $\begin{array}{c}-.0159139 \\
(.0576004) \\
\end{array}$ \\
\hline $\begin{array}{c}\text { Workers } \\
\text { ownership }\end{array}$ & & & & $\begin{array}{c}.0152263 \\
(.5693204)\end{array}$ \\
\hline Managers & & & & $\begin{array}{c}.0744125 \\
(.8567416) \\
\end{array}$ \\
\hline State & & & & $\begin{array}{c}1.135162 \\
(.7350317)\end{array}$ \\
\hline $\begin{array}{c}\text { Physical } \\
\text { entities }\end{array}$ & & & & $\begin{array}{c}.5281672 \\
(.5320371)\end{array}$ \\
\hline $\begin{array}{l}\text { Ukrainian } \\
\text { companies }\end{array}$ & & & & $\begin{array}{c}.9791046 \\
(.5998799) \\
\end{array}$ \\
\hline $\begin{array}{c}\text { Foreign } \\
\text { companies }\end{array}$ & & & & $\begin{array}{c}2.082235^{* * * *} \\
(.4919346)\end{array}$ \\
\hline$R^{2}$ & 0.3202 & 0.3215 & 0.4126 & 0.5036 \\
\hline
\end{tabular}

In parentheses are standard errors; *,**, *** mean $10 \%, 5 \%$ and $1 \%$ significance level respectively. 


\section{Regression results for Model 3}

Table 7. Spillover effects on labor productivity.

\begin{tabular}{|c|c|c|c|c|}
\hline & $\ln \frac{Y_{i t}}{L_{i t}}$ & $\ln \frac{Y_{i t}}{L_{i t}}$ & $\ln \frac{Y_{i t}}{L_{i t}}$ & $\ln \frac{Y_{i t}}{L_{i t}}$ \\
\hline constant & $\begin{array}{c}.8387315 * * * \\
(.2503692)\end{array}$ & $\begin{array}{c}.9339324 * * * \\
(.2723761)\end{array}$ & $\begin{array}{c}.8037184 * * * \\
(.2917585)\end{array}$ & $\begin{array}{c}.7770575 * * * \\
(.2837662) \\
\end{array}$ \\
\hline $\ln \frac{K_{i t}}{L_{i t}}$ & $\begin{array}{c}.1707783 * * \\
(.0788923)\end{array}$ & $\begin{array}{l}.17281 * * \\
(.0795979)\end{array}$ & $\begin{array}{c}.2292445 * * * \\
(.0755159)\end{array}$ & $\begin{array}{c}.2267631 * * * \\
(.0753785)\end{array}$ \\
\hline spillover & $\begin{array}{c}.0029564 * * * \\
(.0007592) \\
\end{array}$ & $\begin{array}{c}.0029796 * * * \\
(.0007643) \\
\end{array}$ & $\begin{array}{c}.0022251 * * * \\
(.0007798) \\
\end{array}$ & $\begin{array}{c}.0023776^{* * *} \\
(0007746)\end{array}$ \\
\hline $\begin{array}{c}\text { Workers } \\
\text { ownership }\end{array}$ & & $\begin{array}{l}-.2742787 \\
(.2454183)\end{array}$ & $\begin{array}{c}-.155701 \\
(.2276825)\end{array}$ & \\
\hline Managers & & $\begin{array}{c}.0620174 \\
(.4177473)\end{array}$ & $\begin{array}{c}.1221477 \\
(.3963747)\end{array}$ & \\
\hline State & & $\begin{array}{l}-.2565311 \\
(.5136659)\end{array}$ & $\begin{array}{l}.4522285 \\
(.4829886)\end{array}$ & \\
\hline $\begin{array}{l}\text { Physical } \\
\text { entities }\end{array}$ & & $\begin{array}{l}.0554883 \\
(.2879311)\end{array}$ & $\begin{array}{l}.0297117 \\
(.2631004)\end{array}$ & \\
\hline $\begin{array}{l}\text { Ukrainian } \\
\text { companies }\end{array}$ & & $\begin{array}{l}-.5306005^{*} \\
(.3026857)\end{array}$ & $\begin{array}{c}-.5987747 * * \\
(.2797578)\end{array}$ & \\
\hline $\begin{array}{c}\text { Foreign } \\
\text { companies }\end{array}$ & & $\begin{array}{l}.7990214 \\
(.9661738)\end{array}$ & $\begin{array}{c}.0781827 \\
(.8985468)\end{array}$ & \\
\hline $\begin{array}{c}\text { Metallurgy } \\
\text { industry }\end{array}$ & & & $\begin{array}{l}.5885331 * \\
(.3363792)\end{array}$ & $\begin{array}{l}.5185387 \\
(.334257)\end{array}$ \\
\hline $\begin{array}{c}\text { Metal } \\
\text { processing }\end{array}$ & & & $\begin{array}{c}-.7742763 * * * \\
(.2774144)\end{array}$ & $\begin{array}{c}-.8045659 * * * \\
(.2710271)\end{array}$ \\
\hline $\begin{array}{l}\text { Wood and } \\
\text { paper }\end{array}$ & & & $\begin{array}{l}-.8716325^{* *} \\
(.4409653)\end{array}$ & $\begin{array}{l}-.8462005^{* * *} \\
(.4235343)\end{array}$ \\
\hline $\begin{array}{l}\text { Construction } \\
\text { materials }\end{array}$ & & & $\begin{array}{l}-.0539755 \\
(.3273139)\end{array}$ & $\begin{array}{l}-.1288253 \\
(.3251478)\end{array}$ \\
\hline $\begin{array}{c}\text { Light } \\
\text { industry }\end{array}$ & & & $\begin{array}{l}-.4108193 \\
(.3406818)\end{array}$ & $\begin{array}{l}-.4664606 \\
(.3348827)\end{array}$ \\
\hline $\begin{array}{c}\text { Food } \\
\text { industry }\end{array}$ & & & $\begin{array}{l}.7299265 \\
(.2758278)\end{array}$ & $\begin{array}{l}.6428868 \\
(.2670187)\end{array}$ \\
\hline$R^{2}$ & 0.0898 & 0.1091 & 0.2734 & 0.2504 \\
\hline
\end{tabular}

In parentheses are standard errors; $*, * * * * *$ mean $10 \%, 5 \%$ and $1 \%$ significance level respectively. 


\section{Regression results for Model 4}

Table 8. Spillover effects on exports.

\begin{tabular}{|c|c|c|c|c|}
\hline & $\ln \operatorname{Exp}_{i t}$ & $\ln \operatorname{Exp}_{i t}$ & $\ln \operatorname{Exp}_{i t}$ & $\ln \operatorname{Exp}_{i t}$ \\
\hline constant & $\begin{array}{l}-1.986797 * \\
(1.081524)\end{array}$ & $\begin{array}{c}-2.522509^{* *} \\
(1.050605)\end{array}$ & $\begin{array}{c}-2.167826^{* *} \\
(1.012107)\end{array}$ & $\begin{array}{l}-2.589027 \\
(1.160966)\end{array}$ \\
\hline $\ln L_{i t}$ & $\begin{array}{c}1.174555^{* * *} \\
(.1607732)\end{array}$ & $\begin{array}{c}1.169415^{* * *} \\
(.1585468)\end{array}$ & $\begin{array}{c}1.164557 * * * \\
(.1541413)\end{array}$ & $\begin{array}{c}1.22317 * * * \\
(.1694424)\end{array}$ \\
\hline spillover & $\begin{array}{l}.0029216^{*} \\
(.0016981)\end{array}$ & $\begin{array}{c}.0028104 * * \\
(.00142)\end{array}$ & $\begin{array}{l}.0028077 * \\
(.0014433)\end{array}$ & $\begin{array}{l}.0032366^{*} \\
(.0017117)\end{array}$ \\
\hline $\begin{array}{c}\text { Workers } \\
\text { ownership }\end{array}$ & & & & $\begin{array}{l}.3753603 \\
(.610116)\end{array}$ \\
\hline Managers & & & & $\begin{array}{c}.7417539 \\
(.9254058)\end{array}$ \\
\hline State & & $\begin{array}{c}1.190222 \\
(.7258599)\end{array}$ & & $\begin{array}{l}1.324532 * \\
(.7662441)\end{array}$ \\
\hline $\begin{array}{l}\text { Physical } \\
\text { entities }\end{array}$ & & $\begin{array}{l}1.051411^{*} \\
(.5439513)\end{array}$ & & $\begin{array}{l}1.233253^{* *} \\
(.5864281)\end{array}$ \\
\hline $\begin{array}{l}\text { Ukrainian } \\
\text { companies }\end{array}$ & & $\begin{array}{c}.8572546 \\
(.6658557)\end{array}$ & & $\begin{array}{c}1.129888 \\
(.7260139)\end{array}$ \\
\hline $\begin{array}{c}\text { Metallurgy } \\
\text { industry }\end{array}$ & $\begin{array}{l}.7174181 \\
(.7039667)\end{array}$ & $\begin{array}{c}.9029099 \\
(.5839055)\end{array}$ & $\begin{array}{l}.9589779 \\
(.5877421)\end{array}$ & $\begin{array}{c}.4705539 \\
(.7169181)\end{array}$ \\
\hline $\begin{array}{c}\text { Metal } \\
\text { processing }\end{array}$ & $\begin{array}{l}-.3159037 \\
(.5702525)\end{array}$ & & & $\begin{array}{l}-.6071945 \\
(.5736704)\end{array}$ \\
\hline $\begin{array}{l}\text { Wood and } \\
\text { paper }\end{array}$ & $\begin{array}{c}.9759838 \\
(2.033107)\end{array}$ & & & $\begin{array}{c}1.248586 \\
(2.006702)\end{array}$ \\
\hline $\begin{array}{c}\text { Constructio } \\
n \text { materials }\end{array}$ & $\begin{array}{l}-1.185085 \\
(1.168831)\end{array}$ & & & $\begin{array}{l}-1.144203 \\
(1.191918)\end{array}$ \\
\hline $\begin{array}{c}\text { Light } \\
\text { industry }\end{array}$ & $\begin{array}{c}.7235154 \\
(.7583744)\end{array}$ & $\begin{array}{l}1.064151^{*} \\
(.6428224)\end{array}$ & $\begin{array}{c}.9691074 \\
(.6497758)\end{array}$ & $\begin{array}{l}.5397828 \\
(.7755485)\end{array}$ \\
\hline $\begin{array}{c}\text { Food } \\
\text { industry }\end{array}$ & $\begin{array}{c}-.283287 \\
(.7596769)\end{array}$ & & & $\begin{array}{c}-.550465 \\
(.7884481)\end{array}$ \\
\hline$R^{2}$ & 0.3659 & 0.3932 & 0.3535 & 0.4082 \\
\hline
\end{tabular}

In parentheses are standard errors; ${ }^{* *},{ }^{* * *}$ mean $10 \%, 5 \%$ and $1 \%$ significance level respectively. 